\title{
Imagicidades telejornalísticas
}

\author{
Image discuss and possibilities in television journalism \\ Imagicidades en teleperiodismo
}

Carlos Fernando Franco ${ }^{l}$

\begin{abstract}
Resumo
O presente ensaio trata da questão da imagem como ferramenta informativa e de constituição de enunciações jornalísticas. Categoriza as naturezas imagéticas mais comuns encontradas nas narrativas jornalísticas. Discute a relação hierarquizada entre imagem e texto. Observa os usos comuns desta forma de expressão na contemporaneidade com relação às novas mídias, percebendo criação de retóricas levianas de foco convergente a determinados grupos. Reflete sobre o caráter universal da imagem e seu uso mais ético e seguro na constituição de enunciações telejornalísticas. Discute a credibilidade da informação quando baseada em imagens. Conclui que a imagem em movimento é o processo comunicacional mais potencialmente isento dentre todos os processos mais utilizados.
\end{abstract}

Palavras-chave: Imagem. Telejornalismo. Paradigma. Mídia.

\begin{abstract}
The present work deals with language as an informative tool and an organization of journalistic enunciations. Categorizes the most common imagistic natures in journalistic narratives. Discusses a hierarchical relationship between image and text. Observations on the contemporary consumption of expression in relation to new media, perceiving the creation of rhetorics of convergent focuses in certain groups. Reflect on the universals of the image and its ethical and safe use in the constitution of telejournalistic utterances. Discusses a credibility of information when based on images. It concludes that moving image is the most effective communicational process among all the processes most used.
\end{abstract}

Keywords: Image. Television. Periodism. Pattern. Media.

\section{Resúmen}

El presente trabajo trata del lenguaje como una herramienta informativa y de una organización de enunciaciones periodísticas. Categoriza las naturalezas imágenes más comunes en las narrativas periodísticas. Discute una relación jerarquizada entre imagen y texto. Observaciones sobre los consumos comunes de expresión en la contemporaneidad con relación a los nuevos medios, percibiendo la creación de retóricas de focos convergentes en determinados grupos. Refleja sobre las universales de la imagen y de su uso ético y seguro en la constitución de enunciaciones telediarios. Discute una credibilidad de la información cuando se basa en imágenes. Concluye que la imagen en movimiento es el proceso comunicacional más eficaz entre todos los procesos más utilizados.

Palabras-clave: Imagene. Tele-periodismo. Paradigma. Media.

\footnotetext{
${ }^{1}$ Professor adjunto do curso de Jornalismo da Universidade Federal do Tocantins. e-mail: profcarlosfranco@uft.edu.br
}

Comun. \& Inf., Goiânia, GO, v. 21, n. 3, p. 123-136, out./dez. 2018. 


\section{INTRODUÇÃO}

presente ensaio tem sua concepção inicial a partir das inquietudes normais a
todas as crises de paradigma. Aprendemos em nossa formação básica que os
modernistas execravam os parnasianos, assim como os realistas o fizeram de encontro aos românticos.

Assim, os partidários da nova mídia enxergam o que pejorativamente chamam de grande mídia ou mídia tradicional, o que se baseia em fluxos unidirecionais, produção em escala empresarial, etc. Retiram credibilidade e pregam tal descrédito não só para com os processos, mas relativo aos conteúdos lá veiculados, dando exagerado valor aos novos modos de consumo e retroalimentação informacional inerentes à contemporaneidade.

Destas inquietações expressas nos questionamentos da geração em voga, procuramos observar e refletir acerca do ferramental técnico do telejornalismo praticado, a partir do qual podemos descrever e perceber a natureza dos processos, tendo como base epistemológica referencial teórico de alguns pensadores do audiovisual. Deste modo, nossa base metodológica é a observação e a descrição de processos e categorização de elementos encontrados na discursividade jornalística praticada na TV. Cabe aqui salientar que existem apropriações de novos processos pela produção dita tradicional. Isto fez com que a mídia tenha se tornado sensível aos anseios e ao controle social vigente que se mune das novas tecnologias.

Outro aspecto que não podemos deixar de abordar é a velada separação processual, que faz com que alguns profissionais sejam mais "textualistas" (conservadores) do que outros "imagicistas" (questionadores). Nosso corpus não está explicitamente descrito por procedimentos de ordem metodológica, pois procuramos uma visão mais ampla dentro de um intervalo de cerca de trinta anos, quando não havia ainda uma ampla utilização de novas tecnologia do modo democrático que observamos atualmente. Muitas das reflexões colocadas aqui são frutos de demandas didáticas observacionais e discussões acerca de processualidades, a fim de desmistificar muito do que se pensa acerca da mídia televisiva.

Ou seja, antes de se acusar a mídia de deturpadora de informações, é preciso compreender a natureza e os processos utilizados, a fim de se poder fundamentar com precisão possíveis posicionamentos.

\section{ISENÇÃO VERSUS AUTORALIDADE}


Existe isenção objetiva no telejornalismo? Tecnicamente falando, a partir de alguns objetos empíricos, podemos dizer que é possível. Vejamos este exemplo: cobertura ao vivo dos protestos de junho de 2013 no Rio de Janeiro, no qual um ônibus está sendo incendiado. A repórter que cobria o acontecimento, de forma inteligente, pediu ao cinegrafista que deixasse a câmera fixa sobre um tripé mostrando ao vivo o que ocorria, com a captação de áudio ambiente acompanhando as imagens. $\mathrm{O}$ que ela poderia ter narrado com palavras sem o risco de se comprometer? Quais as sonoras possíveis naquele momento? As imagens falaram de si e por si e a repórter ou o veículo não se comprometeram pelos ânimos exaltados pelo contexto.

Não houve sonoras ${ }^{2}$, off $s^{3}$, passagens ${ }^{4}$, montagem por edição, nada. Apenas a imagem do acontecido era transmitida ao vivo como um flash de edição extraordinária. Ou seja, existe informação "isenta" ou plenamente objetiva, apesar de um evento não muito comum, dadas as possibilidades de manipulação do material bruto, inerentes ao processo. Assim, isenção não é algo utópico ou teórico, apenas uma oportunidade rara.

No telejornalismo, diferente de outros processos jornalísticos, podemos presenciar discursividades cuja participação autoral é mínima, como no exemplo citado, onde ocorre apenas pela iniciativa de construir recortes de tempo e espaço. Isto não acontece na produção de um texto, pois sua construção sempre terá uma origem subjetiva, oriunda da escolha de léxicos dentre um universo limitado pelo código linguístico e por repertório experiencial de quem produz o discurso. Além disto, escrever é utilizar estilos que tencionam o semântico e dependem do sintático, cujo agenciamento estará no receptor obrigatoriamente letrado. Ou seja, apesar da linearidade inerente e de estruturas cuja percepção se faz em únicos sentido e direção, há sutis possibilidades de estilísticas autorais que podem construir variações passíveis de alteração de sentido.

Aqui comentamos acerca do texto lido pelo receptor. Ao observarmos o texto falado e escutado, há ainda outras facetas interpretativas, pois não devemos nos esquecer de que se trata de um objeto de percepção linear. Diferentemente da imagem visual que não a possui, a linearidade impõe um sequenciamento informacional e força a percepção a segui-la. Ou seja, todos que escutamos tenderemos a perceber algo convergente, pois nossa percepção não buscará outros objetos dispostos perifericamente.

Além disto, há algumas nuances interpretativas que por si só já modificam o modo como potencialmente fruímos o enunciado. Este exemplo a seguir explica melhor, no segmento de

\footnotetext{
${ }^{2}$ Depoimento de terceiro conduzido pelo repórter.

${ }^{3}$ Narração pelo repórter.

${ }^{4}$ Comentário do núcleo da notícia com aparição do repórter em stand-up ou em on.

Comun. \& Inf., Goiânia, GO, v. 21, n. 3, p. 123-136, out./dez. 2018.
} 


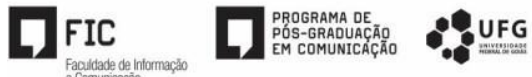

off: "A prefeitura alega que a enchente foi provocada pelo acúmulo de lixo". Se deslocarmos a inflexão exclamativa, já disporemos de outro sentido. Enfatizando "A PREFEITURA alega" soará diferente de "A prefeitura ALEGA" ou "ENCHENTE", "PROVOCADA" e por aí vai. Podemos perceber que em formas de expressão lineares, um simples deslocamento da força inflexiva de uma palavra mudará o sentido de forma importante.

Não estamos aqui alegando possibilidades arbitrárias que possam provocar certas tendenciosidades, mas, mesmo de forma involuntária, o texto pelo seu caráter linear força a interpretação a sentidos, sejam eles léxico-semânticos ou inflexivos.

No fotojornalismo, apesar de o objeto ser retirado diretamente do que comumente chamamos de real, existe uma dependência do texto, no caso legendas ou boxes acessórios em publicações impressas ou digitais. Além disto, o instante não representa um intervalo do acontecimento perceptível e palpável, não havendo um tempo mensurável da enunciação que permita uma fluidez. Isto não desmerece o real exposto pelas fotografias, que quebram uma estrutura impositiva do textual, pois dão alguma liberdade ao receptor através da interpretação pelo universal imagético.

Deste modo, podemos supor que o telejornalismo é o único gênero jornalístico que tem a possibilidade de construir discursividades puras ou não autorais. Isto pode nos fazer pensar que é portador nato de uma realidade plena, ou seja, de um poder infinito. Todavia, há de se observar que não existe em qualquer processo comunicacional emissão sem recepção, nem enunciado sem interpretação ou entendimento. Cabe aqui voltarmos a outra lenda urbana do telejornalismo que foi a edição do debate das eleições brasileiras de 1989. A primeira pergunta que podemos fazer é se uma matéria exibida em um telejornal tem o poder de alterar o resultado das urnas. Isto até pode ser possibilidade, mas será probabilidade? A partir de que subsídios materiais podemos afirmar categoricamente o que foi especulado à época e ainda hoje?

Porém, há elementos neste caso a serem observados: o primeiro a questão do discurso oral, que não especificamente se trata de texto, mas de oralidade improvisada, ligada a um idioleto, ou modo pelo qual cada um de nós constrói um discurso de improviso, a partir do repertório vivencial individual e único.

O segundo é o que tange às imagens exibidas e a um caráter de afetividade do espectador para com a figura enquadrada como imagem televisiva. Por último, há o parâmetro da processualidade jornalística e das imposições do meio televisivo, no que tange às restrições de tempo de exibição. Isto faz com que o editor das imagens já de início fique limitado a este último fator. Ou seja, tendo de montar uma enunciação em um minuto, por exemplo, e dispondo 
de horas de material, as possibilidades de construção são quase infinitas. Além do fato de uma ênfase na tese A ou B ser apenas uma possibilidade ou uma aposta, pois não se trata de algo do campo das ciências exatas 5 .

As imagens visuais, por não serem estruturas nem tampouco constituírem-se de algo cuja percepção seja linear, são percebidas de forma muito individual, diferente de outras formas de expressão lineares como o texto ou as sonoridades, pois possibilitam a percepção de elementos periféricos. Quando em paralelo a outras formas de expressão como a oralidade expressa pelas imagens sonora e visual aumentam ainda mais as possibilidades de construção. Todavia, o que mais joga por terra quaisquer especulações é o fato de determinadas frases fazerem sentido a uns, mas não a outros, pois a interpretação do discurso oral também depende de individualidades, do tipo vivenciais, morais, valorativas, diversa da simples percepção das imagens visuais ${ }^{6}$.

Pesquisar tendo como objeto imagens visuais é muito complexo. Tão complexo quanto utilizá-las materialmente para produzir enunciações.

\section{NATUREZAS DA IMAGEM JORNALÍSTICA EM TV}

A imagem no telejornalismo não se constitui aleatoriamente de objetos dentro de um espaço de percepção em movimento ou não. Há semelhanças composicionais muito próximas do que pode ocorrer com a produção de um texto. Entretanto, diferente desse meio de produção, as escolhas não estão baseadas em um universo particular, vivencial e abstrato, focadas em um código linguístico finito. Ao contrário, um repórter cinematográfico escolhe as suas imagens a partir do que solicita a pauta, e trata-se de munição de repertório, a qual será submetida ao processo manipulatório da edição.

Outro aspecto conceitual que deve ser frisado é o fato de a fonte de tal repertório, especificamente dentro do jornalismo, originar-se exteriormente ao sujeito da composição, agenciada pelo espaço do acontecimento, ligada intimamente ao tempo desse contexto. Ou seja, o repórter buscará imagens representativas reais. Não as criará cenograficamente, a não ser em episódios muito específicos onde uma encenação se faça necessária ou ainda se munindo

\footnotetext{
${ }^{5} \mathrm{O}$ que a publicidade já nos ensinou com campanhas certas do sucesso e que se fadaram ao fracasso.

${ }^{6} \mathrm{E}$ a mídia sempre será o bode expiatório, ao mesmo tempo em que é o pilar mais importante dentro de um contexto de liberdades, dentro do qual podemos criticá-la, boicotá-la, admirá-la ou utilizá-la a nosso favor. Vejamos o que em 2017 o presidente dos EUA Donald Trump mencionou a seu respeito ou em 2016 o que muitos suspeitos de corrupção no Brasil a acusaram.
} 
口FIC

artificialmente de infográficos ou ilustrações que tenham como principal intuito ilustrar. Isto tem como objetivo eximir o profissional ou o veículo de quaisquer responsabilidades acerca do que é noticiado.

Contudo, no caso de ilustrações ou infográficos, assim como ocorre na composição de um texto, há uma dose de interpretação ou criação autoral, a não ser nos casos em que a fonte forneça parâmetros e materiais precisos os quais serão transpostos aos citados processos.

Assim, podemos classificar a natureza das imagens noticiosas como:

a) Descritivas: quando as próprias imagens são a notícia. Um exemplo disto é a cobertura de um acidente automobilístico na qual são mostrados os destroços veiculares. No caso de um deslizamento de terra em uma favela, o local destruído. Ou seja, estão intimamente ligadas ao fato ou são o próprio. A princípio, não há a necessidade de off, pois as próprias imagens com suas sonoridades ambientais dão o tom da notícia.

b) Ilustrativas: representam indiretamente a notícia, mas estão ligadas a ela. No exemplo citado anteriormente, podemos citar imagens das vítimas sendo socorridas. Outro tipo desta natureza são os infográficos ou transposições expressivas insertadas, como fotografias, textos, entre outros; sonoras com especialistas são outro exemplo, bem como a passagem do repórter ${ }^{7}$. Ligam-se ao assunto ou ao fato de forma complementar.

c) Figurativas: são as imagens contextuais, que constituem a base ambiental do acontecido. No caso de um deslizamento de terra, todas as que mostram as condições que tornaram o lugar suscetível ao ocorrido, com suas fragilidades, condições de moradia oferecidas, etc. No caso de um acidente automobilístico, as condições da estrada, quando essa for a possível ou provável causa do ocorrido; sonoras com populares ou fontes desta natureza não ligadas diretamente a um conhecimento de autoridade.

d) Acessórias: erroneamente muito utilizadas no telejornalismo, quando servem apenas para "cobrir" o off, mostrando contextos não diretamente relacionáveis como pessoas andando, imagens do céu ou paisagens, entre outras.

\footnotetext{
${ }^{7}$ Relaciona-se diretamente à notícia, mas tem caráter interpretativo, como outros tipos de inserção, além de focarse no texto.
} 
口FIC

Uma boa reportagem é aquela rica nas três primeiras categorias expostas, ou seja, prioritariamente descritivo-ilustrativa, no caso de um jornalismo mais cotidiano ou de serviço ou ilustrativo-figurativa em reportagens que abordem as problemáticas relacionadas aos acontecimentos, nas quais a ênfase se dá nos elementos determinantes e no contexto, pois a notícia já fora dada. Neste caso, reportagens mais longas, quando há uma relevância social que crie novos agendamentos em potencial. Ou seja, quanto mais nos distanciamos do descritivo, mais interpretativo é o jornalismo praticado e, assim, menos objetividade e isenção teremos, sendo mais opinativos ou autorais. Isto não quer dizer que estamos produzindo ou criando notícias e não trazendo informações, mas sim adicionando subjetividades estilísticas ao processo produtivo. Obviamente, dentro de coerentes parâmetros éticos e de credibilidade das fontes.

\section{IMAGEM VERSUS TEXTO}

Está no campo da tradição dos profissionais ou estudiosos do jornalismo televisivo relegar à imagem um plano de acessorialidade. Para o ato de informar, o texto para o jornalista brasileiro é o elemento mais importante. Como diz Paternostro:

Não vamos ver aqui a imagem como uma rainha, que se impõe aos seus súditos pela simples presença. Mas não podemos deixar de pensar que a imagem é uma linguagem universal, tem um entendimento imediato e possibilita às pessoas a visão de uma realidade externa àquela em que vivem. (PATERNOSTRO, 2006, p. 85).

Se não fosse pela imagem, não haveria o porquê do telejornalismo. Por que os telejornais não informam por notas secas apenas? Cabe aqui salientar outra questão: o uso inadequado de material imagético na composição das matérias, nas quais os profissionais compositores das mesmas, no afã da preocupação com texto, as relegam a funções secundárias. Desta forma, vamos observar algumas características do texto telejornalístico que o fazem tão importante para os profissionais.

Ainda segundo Paternostro (2006, p.85), “[e]m telejornalismo, a preocupação é fazer com que texto e imagem caminhem juntos, sem um competir com o outro[...]". Todavia, como definir esta competição? O texto em uma matéria é falado, gravado, editado, ou seja, está submetido a uma lógica audiovisual a princípio e midiática, por dispor de um tempo enunciatório (FRANCO, 2010) que determina o intervalo pelo qual será percebido. Em um produto jornalístico de um minuto, por exemplo, teremos cerca de trinta e cinco ou quarenta 


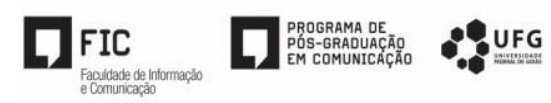

segundos de texto montado, composto pelo jornalista como o off, a passagem quando couber, excetuando-se as sonoras, pois, apesar de editadas obviamente, não possuem autotralidade original profissional, por serem ditas de improviso por depoentes.

Percebamos que a linguagem codificada textual sempre terá caráter linear, como já mencionado. Lendo ou escutando a decodificamos de forma uniforme, na medida em que compreendemos o que é dito, estando em nossa língua ou outra a qual entendamos. Porém, há um caráter de linearidade muito maior nas formas de expressão fluxórias, entendidas como oralizadas como no rádio, na televisão ou nos podcasts digitais da internet, geralmente apropriados das citadas mídias.

O texto pode ter naturezas funcionais similares às das imagens, ou seja, descritivo, ilustrativo, figurativo ou acessório. Entretanto, quando em sincronia com descritivas, ao se buscar um equilíbrio, não deveriam sê-la, pois aí aconteceria o que a anteriormente citada autora define como competição. Assim sendo, dentro de uma coerência informacional, imagens descritivas harmonizam-se com textos acessórios ou ausência deles, na medida em que a composição da imagem, sua captura, subentenderá paralelismo com sonoridades ambientais, pois trata-se de um objeto audiovisual.

Partindo do mesmo raciocínio, nessa linha composicional, um texto figurativo pode se harmonizar com imagens ilustrativas, pois esta natureza remete-se a contextualizações que a imagem trará através de relações diretas com o fato, mas não ele próprio. A recíproca será verdadeira, pois imagens figurativas, de contexto, harmonizar-se-ão com textos ilustrativos, que se remetem ao fato, não o sendo diretamente. Esta relação de equilíbrio é o que se espera de uma boa composição, onde não haverá saturação por redundância (competição), o que facilita a compreensão por parte do espectador.

E quando houver sobreposições de natureza? Neste caso, haverá uma tendência ao sensacionalismo ou à espetacularização. No caso de uma imagem descritiva de um deslizamento em uma favela, como citamos anteriormente, a presença de um texto off de mesma natureza satura informacionalmente a matéria, criando um efeito interpretativo ou opinativo, não dando margem a um agenciamento por parte do espectador do conteúdo. Se vemos uma tragédia claramente, concluindo os motivos óbvios de seu acontecimento e escutamos um texto que converge ou paraleliza o pensamento, nossa tendência será consolidar as conclusões e não refletir, pois já se refletiu, ou nos sentirmos desprezados em nossa capacidade interpretativa; pois a reflexão nos vem pronta. É como se naquele momento conclusões e opiniões aflorassem 
e fossem reforçadas pela audição ${ }^{8}$. O jornalista tenderia a ser, neste caso, equivalente a um juiz que condena todo e qualquer suspeito pelo acontecido. Pois se reforçam pela soma de iguais parcelas as naturezas imagéticas e textuais, tornando o resultado enjoativo como um alimento muito temperado.

O mesmo ocorre com textos e imagens ilustrativas em paralelo, que criam enunciações opinativas fortes, mesmo com naturezas figurativas que, no caso de imagem e texto, passam a enfatizar muito mais o contexto, anulando quase que por completo referências ao acontecido, ficando no plano das informações periféricas.

Um exemplo claro da força da imagem em prol de uma verdade mais próxima do real está na cobertura de uma manifestação, onde são mostradas pessoas na rua protestando e o repórter diz "cerca de dez mil pessoas segundo a PM e vinte mil segundo os organizadores" e o espectador vê claramente que o número pode ser muito maior até do que o dito pelos promotores do evento, pois conhece o espaço da região. Muitos polemizam interesses do veículo na diminuição do número, mas o que geralmente ocorre são divulgações não claramente apuradas. $\mathrm{O}$ fato é que não se disse o número, mas se mostrou a massa de pessoas, ou seja, o repórter e o veículo disseram a pura verdade, mesmo que a informação não tenha sido precisa através do texto; pois a imagem não mente ${ }^{9}$.

A principal característica textual que deve ser frisada: não se trata de uma linguagem universal. Uma imagem a princípio, dentro do que poderíamos chamar de normalidade perceptual, excetuando-se desvios de ordem cognitiva, é uma linguagem universal, reconhecida por qualquer um, mesmo que submetido a contextos culturais diversos. Porém, segundo Arbex:

Não existe o "observador neutro". Testemunhar um evento é também construilo segundo o aparelho psíquico e a formação social e cultural da testemunha. Seria equivocado, por isso, opor radicalmente, de forma maniqueísta, uma suposta "neutralidade objetiva" daquele que presencia diretamente um acontecimento à "intencionalidade manipuladora" da câmara de televisão. (ARBEX, 2001, p. 35).

Existe uma convergência perceptual na remetência primária a um elemento reconhecido na composição. Mesmo que a imagem não seja uma linguagem de caráter linear como o tex to ${ }^{10}$,

\footnotetext{
${ }^{8}$ Ou vou de encontro ao jornalista, discordando, ou concordo com ele e não reflito mais. É uma questão de "margem" para o pensamento.

${ }^{9}$ Nunca devemos subestimar a inteligência do público. A verdadeira informação sempre será interpretada por ele e através do visto, muito mais do que do ouvido ou lido.

${ }^{10}$ Pois não a varremos de cima e à esquerda para baixo, mas somos atraídos por elementos que se enfatizam nela, nos chamando à atenção.
} 
que é reconhecido no telejornalismo a partir de uma linearidade sonora; é mais facilmente percebida, mesmo por indivíduos não letrados.

Para Aumont, o sujeito que percebe as informações imagéticas:

[N]ão é de definição simples, e muitas determinações diferentes, até contraditórias, intervêm em sua relação com uma imagem: além da capacidade perceptiva, entram em jogo o saber, os afetos, as crenças [...]. Entretanto, apesar das enormes diferenças que são manifestadas na relação com a imagem particular, existem constantes consideravelmente trans-históricas e até interculturais, da relação do homem com a imagem em geral. (AUMONT, 2006, p. 77).

Voltando ao caso das imagens ilustrativas. Elas podem ter um caráter não apenas representativo, mas simbólico (AUMONT, 2006), ou seja, podem ser percebidas como imagens, mesmo não descrevendo uma representação concreta das mesmas. Isto é muito comum no caso de trechos de texto utilizados para corroborar o que os textos de fato estão dizendo. Vemos muito desses exemplos quando alguém é condenado ou investigado e se colocam trechos destacados dos autos do processo. Trata-se de um texto, que é lido pelo espectador como tal, mas durante um tempo determinado pelo processo de edição da matéria, além de efeitos de destaque que frisam determinados trechos focados no reforço da notícia; ou seja, possui uma audiovisualidade (KILPP, 2009) clara. Neste caso, trata-se de uma linguagem interpretada ou descrita a partir de outra, cujo caráter é diverso. Aumont diz que "para Arnheim, uma imagem serve de signo quando representa um conteúdo cujos caracteres não são visualmente refletidos por ela" (AUMONT, 2006, p. 79). Quando dizemos que houve um acidente envolvendo um automóvel, cada um dos que ouvem a mensagem imagina um veículo diverso. O que é diferente do uso de uma imagem descritiva, cujas características visuais do modelo são claras.

\section{EDIÇÃO VERSUS AO VIVO}

$\mathrm{Na}$ história do telejornalismo temos ícones que merecem uma discussão. Nos anos noventa, a guerra no Golfo foi o primeiro evento belicoso transmitido ao vivo que se tem notícia. Cabe aqui observar que as imagens geradas pela câmera de visão noturna que mostravam a artilharia antiaérea podem ser observadas sob dois aspectos: a descrição do acontecimento e a ilustração do fato. Ou seja, víamos claramente que se tratava de uma guerra, 


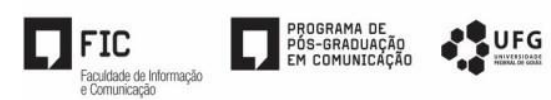

mas não podíamos perceber toda a capilarização trágica do evento em terra. Muitos daqueles mísseis não eram interceptados e caíam na população civil.

No momento, os espectadores do mundo inteiro que acompanhavam o evento percebiam apenas o acontecimento ao nível do fato, pois os comentaristas não podiam sequer ver o que realmente acontecia nos interstícios daquela cidade sob ataque. Posteriormente, após as batalhas, quando foi possível a penetração de equipes de reportagem nos locais, pudemos perceber as dimensões quase reais do acontecido.

Obviamente, no caso, cada emissora, com seu perfil editorial e sua equipe alinhada às suas regras e critérios de noticiabilidade produziu reportagens com enfoques diversos, mas supostamente com o profissionalismo e ética aceitáveis.

Nesse segundo momento, as imagens capturadas foram transformadas em matérias, editadas, sincronizadas com narrações. Muitas sonoras foram gravadas, além de passagens de repórteres. O descritivo do acontecimento e o ilustrativo do fato foram convertidos em notícias, subordinadas aos perfis editoriais das empresas jornalísticas, bem como, principalmente, passaram a ter seu caráter autoral.

Nos dias atuais, com o desenvolvimento da tecnologia, é possível produzir transmissões ao vivo munindo-se de um smartphone e de uma conexão razoável à internet. Assim surgem novos processos de comunicação, sem o chamado crivo empresarial, execrado por muitos. Todavia, até que ponto isto pode ser considerado jornalismo? Sabemos que não haverá limitações de tempo e espaço midiáticos televisuais e que qualquer um munido do citado equipamento básico terá capacidade de mostrar um real. Que tipos de realidade e isenção serão possíveis a partir desse novo fenômeno? Devemos sempre considerar o extremo da enunciação, ou seja, o lado do observador.

Trata-se de uma nova dimensão do que tradicionalmente chamamos de informação ao vivo. Voltemos aos protestos do ano de 2013. Muitos já acompanhavam seu desenrolar por esses citados canais. As imagens geradas não tinham cortes. Muitas vezes trechos de tais informações são editados e redistribuídos por meio de redes sociais telemáticas. Portanto, mesmo tratando-se de olhares não cotidianamente profissionais, podemos questionar a aura de "mídia livre" de tais meios, pois, quando editadas, as imagens tornam-se sujeitas a autoralidades que, no caso, são distribuídas a um grupo estrita e ideologicamente alinhado, cujo consumo tende a ser o que se deseja, sem contrapontos; no caso, sonoras do contraditório, por exemplo.

Há ainda outra dimensão acerca das imagicidades: a reedição do que é veiculado pela televisão e distribuição pelos novos canais citados. O que observamos são possibilidades de 


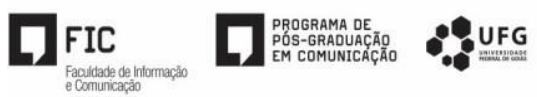

deturpações do sentido original, através da omissão de sonoras ou imagens ilustrativas. Pois trata-se de munir-se do primário, das imagens brutas gravadas enquanto estavam ao vivo ou do secundário, com caráteres autorais e editoriais e passando à dimensão interpretativa, de um terciário. Isto tem se tornado muito comum e percebemos que, devido à intimidade que os usuários criam com o cotidiano consumo desses meios de comunicação, são-lhes dados muito crédito, mesmo que não tenham sido produzidos por profissionais, dentro de parâmetros técnicos e éticos.

Muitas vezes, imagens descritivas tornam-se acessórias ou apenas ilustrativas e são utilizados textos de natureza estritamente opinativa, de forma conativa, dentro do que pensam ou anseiam os receptores daquele determinado grupo.

Voltemos à solução de isenção dada pela repórter, comentada ao início deste ensaio. A partir do momento em que cortamos e colamos, adicionando um texto, distanciamo-nos do que poderíamos chamar de objetividade.

O ao vivo, ao se tornar documento manipulado pela edição, despe-se do seu caráter absolutamente objetivo, tornando-se relativo. Diferente de um simultâneo comentado, onde temos a liberdade de descartar os comentários e perceber de modo livre o que as imagens descrevem.

Muitos, sem conhecer a complexidade e o custo do jornalismo empresarial ético, acusam-no de potencialmente deturpar informações, pois podem-se editar imagens, sincronizalas com narrações que têm o potencial de trazer valores persuasivos. Perguntamos: se a televisão tradicional tem a real possibilidade de fazer isto, por que a nova mídia também não teria, já que os processos tanto de manipulação quanto de divulgação se equivalem? Trata-se aqui de perceber o quão objetiva é uma informação. Para isto, somente as imagens com sua natureza mais próxima do real podem parametrizar realidades acusatórias.

\section{CONSIDERAÇÕES FINAIS}

Apesar de estarmos vivendo em uma contemporaneidade repleta de imagens, a retórica ainda se faz pelo texto. A internet com suas redes sociais é a fonte de informação mais acessada atualmente. Já podemos dizer que existe uma geração que não assiste televisão, não a conhece ou sequer tem algum interesse nessa mídia.

A questão central para o jornalista é a utilização das imagens como forma de respaldo, principalmente de modo ético, baseando-se no caráter indiscutível do que é visto através de 
uma forma de expressão universal. Obviamente, não desmereçamos o discurso textual, pois é através dele que temos o caráter documental da notícia, bem como a possibilidade de percepção de estilos dos profissionais.

Tanto a imagem quanto o texto, pelo crivo profissional, têm a possibilidade de manipulação, mas isto não quer dizer que tenham sido deturpados os seus sentidos. Ao contrário, é a partir de processos manipulatórios que se adequam as enunciações às restrições impostas pelos paradigmas midiáticos, tais como tempo, espaço, entre outros.

Portanto, respeitemos as imagens, pois elas têm um custo alto de produção e são o que está mais próximo de uma realidade, na medida em que não são frutos de estilísticas ou repertórios pessoais, mas agenciam-se no ambiente o qual queremos penetrar a fim de mostrar realidades. Se contra fatos não haverá argumentos, contra imagens, menos ainda.

\section{REFERÊNCIAS}

ARBEX JÚNIOR, José. Showrnalismo: a notícia como espetáculo. São Paulo: Casa Amarela, 2001.

AUMONT, Jacques. A imagem. São Paulo: Papirus, 2006.

FRANCO, Carlos F. M. Temporalidades audiovisuais. São Paulo: Livronovo, 2010.

HOINEFF, Nelson. A nova televisão. Rio de Janeiro: Relume Dumará, 1996.

KILPP, Suzana. Audiovisualidades nas mídias. Viamão: Entremeios, 2009.

MACHADO, Arlindo. A televisão levada a sério. São Paulo: Senac, 2000.

PATERNOSTRO. Vera Íris. O texto na tv: manual de telejornalismo. Rio de Janeiro: Elsevier, 2006. 